\title{
Genes for Hormone Biosynthesis and Regulation Are Highly Expressed in Citrus Flowers Infected with the Fungus Colletotrichum acutatum, Causal Agent of Postbloom Fruit Drop
}

\author{
Wei Li, Rongcai Yuan, Jacqueline K. Burns, ${ }^{1}$ L.W. Timmer, ${ }^{2}$ and Kuang-Ren Chung ${ }^{3}$ \\ Citrus Research and Education Center, IFAS, University of Florida, Lake Alfred, FL 33850
}

AdDitional index words. abscission, calamondin, ethylene, indole-3-acetic acid, jasmonic acid, 'Valencia' sweet orange

Abstract. Colletotrichum acutatum J. H. Simmonds infects citrus flower petals, causing brownish lesions, young fruit drop, production of persistent calyces, and leaf distortion. This suggests that hormones may be involved in symptom development. To identify the types of hormones, cDNA clones encoding proteins related to ethylene and jasmonate (JA) biosynthesis, indole-3-acetic acid (IAA) regulation, cell-wall modification, signal transduction, or fruit ripening were used to examine differential gene expressions in calamondin (Citrus madurensis Lour) and/or 'Valencia' sweet orange (Citrus sinensis Osbeck) after $C$. acutatum infection. Northern-blot analyses revealed that the genes encoding 1-aminocyclopropane-1-carboxylate (ACC) oxidase and 12-oxophytodienoate required for ethylene and JA biosynthesis, respectively, were highly up-regulated in both citrus species. Both gene transcripts increased markedly in petals, young fruit and stigmas, but not in calyces. The transcripts of the genes encoding IAA glucose transferase and auxin-responsive GH3-like protein, but not IAA amino acid hydrolyase, also markedly increased in both species 5 days after inoculation. The expansin and chitinase genes were slightly up-regulated, whereas the senescence-induced nuclease and B-galactosidase genes were down-regulated in calamondin. No differential expression of transcripts was detected for the genes encoding expansin, polygalacturonase, and serine-threonine kinase in sweet orange. As compared to the water controls, infection of $C$. acutatum increased ethylene and IAA levels by 3 - and 140-fold. In contrast, abscisic acid (ABA) levels were not significantly changed. Collectively, the results indicate that infection by $C$. acutatum of citrus flowers triggered differential gene expressions, mainly associated with IAA, ethylene, and JA production and regulation, and increased hormone concentrations, consistent with the hypothesis of the involvement of phytohormones in postbloom fruit drop.

Postbloom fruit drop (PFD) of citrus is caused by Colletotrichum acutatum J.H. Simmonds, and is characterized by necrotic brown lesions on petals, blossom blight, and premature fruit drop (Timmer and Brown, 2000). PFD was first noticed in 1956, but the description of disease and its causal fungus were reported two decades later (Fagan, 1979). Since then, PFD has been widespread in the humid tropics and subtropics of the Americas, and has become a limiting factor for citrus production in many areas (Timmer and Brown, 2000). PFD causes significant yield loss due to induction of young fruit abscission, sometimes up to $100 \%$ without fungicide applications.

Colletotrichum acutatum infects almost all citrus but limes (Citrus aurantifolia Christm.) and lemons (Citrus limon Burm.). Among them, 'Navel', 'Natal' and 'Valencia' sweet oranges (C. sinensis Osbeck) are the most susceptible. Colletotrichum acutatum survives as appressoria on vegetative tissues to form quiescent infections. Unlike other Colletotrichum species, $C$. acutatum does not invade citrus tissues on which the quiescent stage is formed. Rather, appressoria germinate to form hyphae

Received for publication 16 Oct. 2002. Accepted for publication 18 Feb. 2003 We are grateful to W.O. Dawson and K.S. Derrick (University of Florida) for their critical review. This research was supported by the Florida Agricultural Experiment Station and a grant from the Florida Citrus Production Research Advisory Council (FCPRAC) grant \#012-04P, and approved for publication as Journal Series No. R-08919.

${ }^{1}$ Horticultural Sciences Department, IFAS, University of Florida, 1453 Fifield Hall, Gainesville, FL 32611.

2Plant Pathology Department, IFAS, University of Florida, 1453 Fifield Hall, Gainesville, FL 32611.

${ }^{3}$ Assistant professor of plant pathology, Department of Plant Pathology, IFAS, University of Florida, 700 Experiment Station Rd., Lake Alfred, FL 33850. To whom reprint requests should be addressed; e-mail krchung@lal.ufl.edu. and a few conidia which infect flower petals. During bloom, conidia are splash-dispersed from flower to flower. The fungus infects and reproduces only on flower petals. Thus, the incidence of PFD disease is highly dependent on the amount of rainfall and off-season blooming (Timmer et al., 1994).

The most distinguishing characteristics of PFD are induction of young fruit abscission and formation of persistent calyces, commonly called buttons, that remain attached to the tree (Timmer et al., 1994). The persistent calyces are attached on the peduncles and are only found on the affected flower clusters, providing a year-round diagnostic symptom. The healthy flowers and fruit adjacent to affected flowers also tend to drop before setting fruit, and form persistent calyces. Some affected fruit remain on the peduncles, but their development is prevented. Leaves on affected inflorescences are usually small, chlorotic and twisted with enlarged veins. Thus, phytohormones may be involved in symptom development associated with PFD (Timmer and Brown, 2000). The identities of these hormones remain unknown.

Little is known of the mechanisms by which C. acutatum infects citrus petals and results in young fruit drop. A recently developed transformation system will facilitate genetic manipulation of the causal fungus for identification and analysis of genes required for fungal pathogenicity or virulence (Chung et al., 2002). To understand the possible mechanisms for young fruit drop, we examined the differential expression patterns of cDNA clones related to hormone biosynthesis and regulation in the flowers of calamondin (Citrus madurensis Lour) and 'Valencia' sweet orange after $C$. acutatum infection. The genes encoding ethylene and jasmonic acid (JA) biosynthetic pathways, and indole-3-acetic acid (IAA) regulation are highly up-regulated in the PFD-affected flowers. The amounts of IAA and ethylene, but not abscisic acid 
Table 1. Gene clones used in this study to examine the expression patterns in citrus flowers infected with Colletotrichum acutatum were identified from the abscission zone of 'Valencia' sweet orange (Citrus sinensis Osbeck) specifically activated by an abscission compound 5-chloro-3methyl-1-nitro-pyrazole $\left(200 \mathrm{mg} \cdot \mathrm{L}^{-1}\right)$.

\begin{tabular}{|c|c|c|c|c|}
\hline $\begin{array}{l}\text { Clone } \\
\text { no. }\end{array}$ & $\begin{array}{l}\text { Size } \\
(\mathrm{bp})\end{array}$ & $\begin{array}{l}\text { Putative } \\
\text { identity }\end{array}$ & $\begin{array}{l}\text { Putative } \\
\text { function }\end{array}$ & $\begin{array}{l}\text { Accession no. of } \\
\text { the highest match }\end{array}$ \\
\hline 21 & 378 & $\begin{array}{l}\text { UDP-glucose:salicylic acid } \\
\text { glucosyltransferase; IAA glucose transferase }\end{array}$ & Transfers glucose to salicylic acid and IAA & $\begin{array}{l}\text { AAF61647 } \\
\text { AAD30627 }\end{array}$ \\
\hline 26 & 716 & Polygalacturonase & Cell wall depolymerization & AF095577 \\
\hline 38 & 458 & Chitinase & Plant defense & AAC35981 \\
\hline 62 & 377 & IAA amino acid hydrolase & Free IAA from conjugated form & CAA09330 \\
\hline 64 & 380 & ACC oxidase & Ethylene biosynthesis & BAA19605 \\
\hline 69 & 732 & Serine/threonine kinase & Signal transduction & AAF26468 \\
\hline 81 & 477 & Putative ripening-related protein & Unknown & CAB85628 \\
\hline 89 & 731 & Endo- $\beta-1,3$-glucanase & PR protein & T05262 \\
\hline 102 & 264 & Auxin-reponsive GH3-like protein & Unknown & AAD32141 \\
\hline 159 & 510 & 12-oxophytodienoate reductase & JA biosynthesis & AAC78441 \\
\hline 213 & 231 & Senescence-induced nuclease & Unknown & AAD00694 \\
\hline 243 & 347 & Expansin & Cell wall growth and depolymerization & AAC33530 \\
\hline 258 & 212 & ß-galactosidase & Cell wall depolymerization & P48981 \\
\hline
\end{tabular}

(ABA) were also highly accumulated. High levels of IAA and ethylene may result from de novo biosynthesis from the host plant and/or the fungal pathogen. Recently, the production of IAA by $C$. acutatum in culture was observed (unpublished data), suggesting that $C$. acutatum may play a role in increasing IAA. We also analyzed the expression patterns of the genes for signal transduction and cell-wall modification that have been suggested to be related to fruit abscission. The results suggest that imbalance of IAA, ethylene and JA in C. acutatum-infected flowers may be involved in young fruit drop and other symptoms.

\section{Materials and Methods}

Biological Materials and THEIR MaintenANCE. Calamondin producing off-season inflorescences and sweet orange were selected for the assessment of gene expression after inoculation of C. acutatum J. H. Simmonds. Both species are highly susceptible to $C$. acutatum. Plants were maintained in a screenhouse (Citrus Research and Education Center, Lake Alfred, Fla.), and development of inflorescences usually occurs in February-March in Florida. Fungal isolates (SM3 and SRL-FTP) of C. acutatum were recovered from infected flower petals of sweet orange in Florida (Chung et al., 2002), and were subsequently single-spore isolated. For longterm storage, fungus was grown on a layer of sterilized filter paper, and stored at $-20^{\circ} \mathrm{C}$. Fungal cultures were maintained routinely on potato dextrose agar (PDA, Difco, Detroit, Mich.). For inoculation, fungal cultures were grown on PDA under continuous fluorescent light for $5 \mathrm{~d}$, and conidia were washed off with sterile water. After washing once with water, conidia were harvested by centrifugation (5000 gn for $5 \mathrm{~min}$ ), and the concentration was adjusted to 5 $\times 10^{4}$ conidia per $\mathrm{mL}$. The conidial suspension was sprayed onto calamondin or sweet orange flowers at full bloom using a SpraTool sprayer (Crown, Woodstock, Ill.), and the inoculated flower clusters were covered with a plastic bag for $16 \mathrm{~h}$ to allow infection. The control plants were sprayed with water only. The affected petals developed water-soaked, orange brown lesions after 4 to $5 \mathrm{~d}$. The affected flowers including young fruit were harvested at 2-d intervals postinoculation. Some calamondin flowers were separated into petals, fruit, stigmas, or calyces. Samples were frozen in liquid nitrogen, and immediately subjected to total RNA isolation.

DNA MANIPULATION AND PROBE LABELING. Several hundred
cDNA fragments that were differentially expressed after abscission agent (200 $\mathrm{mg} \cdot \mathrm{L}^{-1}$ 5-chloro-3-methyl-1-nitro-pyrazole) application were identified by subtraction hybridization from cDNA libraries prepared from fruit abscission zones of 'Valencia' (Burns, 2002). The cDNA fragments were end-filled with adaptors (Clontech, Palo Alto, Calif.), then amplified by PCR using two linker primers (5'-TCG AGC GGC CGC CCG GGC AGG T-3' and 5'AGC GTG GTC GCG GCC GAG GT-3') and directly cloned into pGEM-T vector (Promega, Madison, Wis.) for sequence analyses. Database searches and comparisons were conducted using the BLAST network service at National Center for Biotechnology Information (NCBI) and ExPASy Molecular Biology servers. Oligonucleotide primers were synthesized by Integrated DNA Technologies (Coralville, Iowa). In total, 13 cDNA clones related to hormone regulation, signal transduction, cell wall modification, and pathogen defense (Table 1) were selected to examine their regulation before PFD development after $C$. acutatum infection. Expression of the genes encoding senescence-induced nuclease and B-galactosidase was tested only in the calamondin, whereas genes encoding polygalacturonase and serine/threonine kinase were tested only in 'Valencia' sweet orange. Nine other cDNA clones were examined for differential expression in both citrus species. Plasmid DNA was propagated in Escherichia coli DH5 $\alpha$ competent cells (Invitrogen Life Technologies, Carlsbad, Calif.), and was isolated with a Wizard DNA purification kit (Promega). DNA probes used for northern-blot analyses were labeled by PCR incorporation of digoxigenin (DIG)-11-dUTP (Roche Applied Science, Indianapolis, Ind.) using the linker primers. The conditions used for PCR amplification and labeling were as previously described (Chung et al., 1996).

RNA ISOLATION AND NORTHERN-BLOT ANALYSIS. Total plant RNA was extracted with a RNA Isolator kit (Invitrogen). For RNA blotting analyses, $\approx 10 \mu \mathrm{g}$ of total RNA was denatured in a $5 \times$ RNA loading buffer [ $40 \mathrm{~mm}$ ethylene diaminetetraacetate (EDTA), pH8.0; 1 м formaldehyde; $20 \%$ glycerol; $0.3 \%$ formamide; $0.16 \%$ saturatured bromophenol blue; $4 \times$ gel running buffer] at $65^{\circ} \mathrm{C}$ for $5 \mathrm{~min}$. The running buffer containing $200 \mathrm{~mm}$ 3-N-[morpholino]propanesulfonic acid (MOPS); 50 mm sodium acetate and 10 mm EDTA ( $\mathrm{pH} 7.0$ ) was prepared as a $10 \times$ stock solution. The denatured RNA was separated by electrophoresis in formaldehyde-containing agarose gels (1.2\%), and transferred onto 


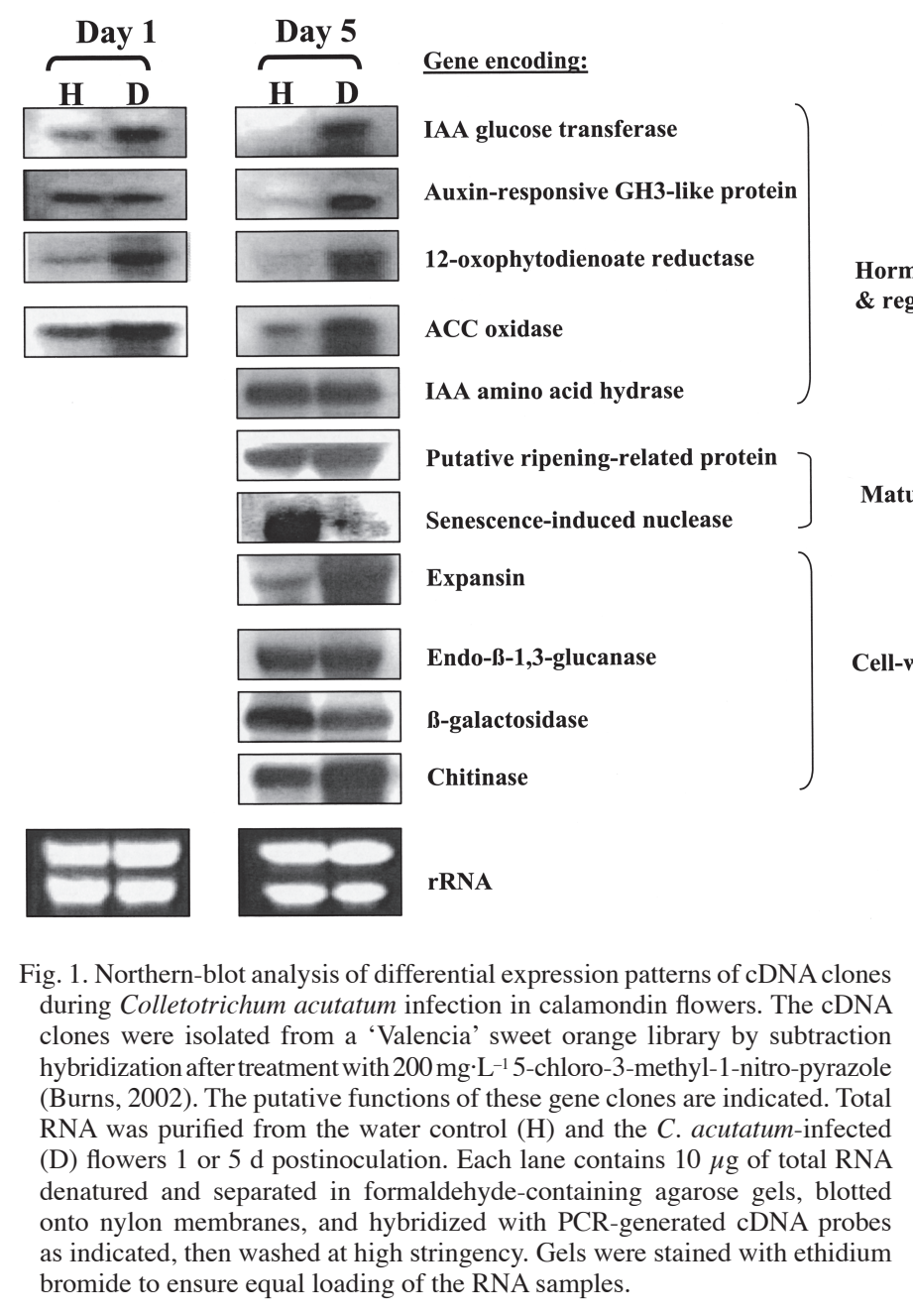

positively charged nylon membranes (Osmonics, Westborough, Mass.). Hybridizations using PCR-generating DNA probes were performed in the PerfectHyb solution (Sigma, St. Louis, Mo.) at $68{ }^{\circ} \mathrm{C}$ for $3 \mathrm{~h}$. After hybridization, membranes were washed in $0.1 \times$ SSC and $0.1 \%$ sodium dodecyl sulfate (SDS) at $68^{\circ} \mathrm{C}$ for 1 h. Immunological detection of labeled probe using CSPD readyto-use chemiluminescent substrate for alkaline phosphatase was conducted according to manufacturer's recommendation (Roche Applied Science, Indianapolis, Ind.).

Purification and detection of Plant hormones. After $C$. acutatum inoculation, necrotic lesions on flower petals usually appeared in $5 \mathrm{~d}$. The amounts of ethylene, IAA, and ABA were measured in calamondin flowers $5 \mathrm{~d}$ after inoculation. Ethylene was collected from an individual flower sealed with a $50-\mathrm{mL}$ syringe with plastic stoppers. Ethylene production was determined using a gas chromatograph as described by Hartmond et al. (2000), and its concentration was indicated in $\mathrm{nL}$ per flower. IAA and ABA were purified from flower petals with $80 \%$ methanol as described by Yuan et al. (2001) and further separated by high performance liquid chromatograph (HPLC) according to the method of Miller et al. (1987). The amounts of IAA and ABA (presented by pmole per gram of fresh weight) were quantified with enzyme-linked immunosorbent assay (ELISA) using monoclonal antibodies (Phytodetek, Elkhart, Ind.) according to the manufacture's recommendation. All treatments with three replicates were performed twice.

\section{Results}

Previous observation indicated that phytohormones are likely involved in young fruit drop caused by $C$. acutatum. To identify the types of phytohormones and other factors involved in PFD, the patterns of gene expression during C. acutatum infection were assessed in northern-blot analysis using cDNA clones associated with mature fruit abscission of 'Valencia' sweet orange. Calamondin and 'Valencia' sweet orange, both equally susceptible to PFD, were selected for gene expression after fungal infection. In addition, calamondin producing off-season flowers all year long can provide sufficient flowers for testing fungal pathogenicity, and for evaluating the effect of hormone inhibitors on preventing young fruit drop. In total, $13 \mathrm{cDNA}$

ell-wall modification clones encoding proteins related to hormone biosynthesis and regulation, cell-wall modification, signal transduction, or mature fruit-related proteins were examined for their expression patterns in healthy and in C. acutatum-infected citrus flowers (Table 1). The cDNA was labeled with digoxigenin and used as a probe to hybridize the total RNA isolated from calamondin flowers treated with the water or conidial suspension of $C$. acutatum (Fig. 1). As compared to the water control, the gene encoding IAA glucose transferase was highly up-regulated in C. acutatum-infected flowers 1 and $5 \mathrm{~d}$ postinoculation. In contrast, expression of the gene encoding IAA amino acid hydrase was constitutively expressed. The gene encoding auxin responsive $\mathrm{GH} 3$-like protein was highly expressed

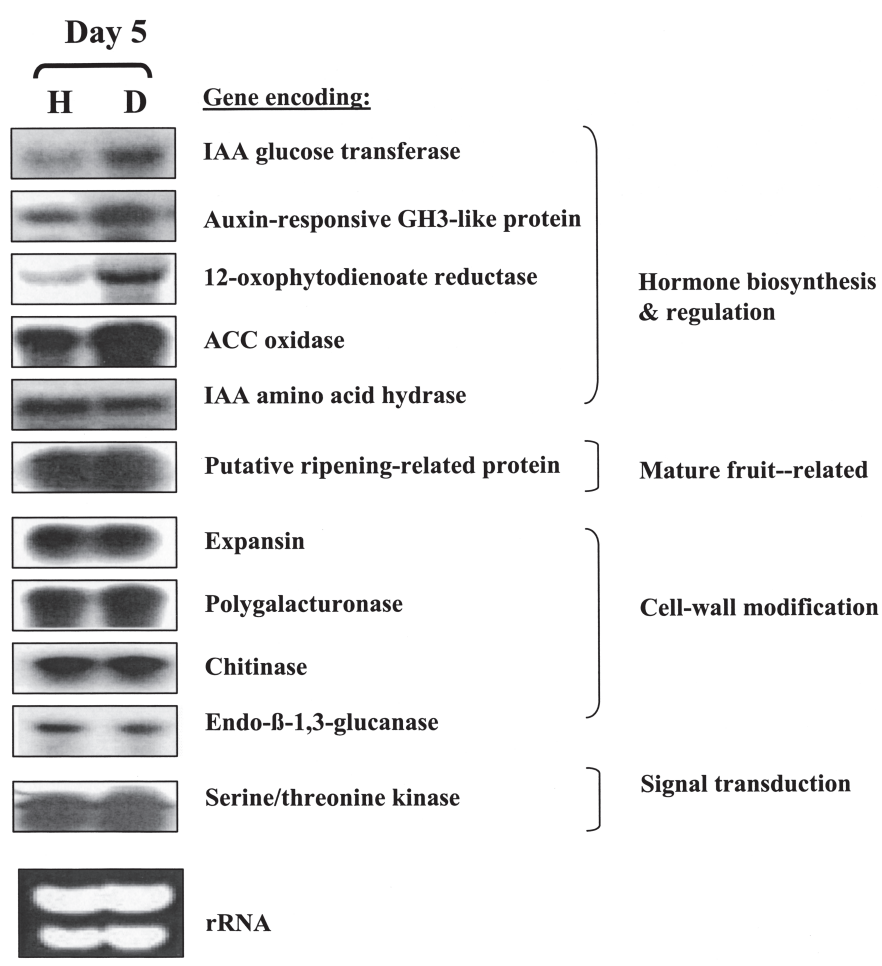

Fig. 2. RNA gel blot analysis of differential expression patterns of cDNA clones as indicated in Table 1 during C. acutatum infection in 'Valencia' sweet orange flowers. Total RNA was purified from the water control $(\mathrm{H})$ and the $C$. acutatum-infected (D) flowers 5 d postinoculation, gel electrophoresed, blotted to membranes, probed, and washed at high stringency. Gels were stained with ethidium bromide to ensure equal loading of the samples. 

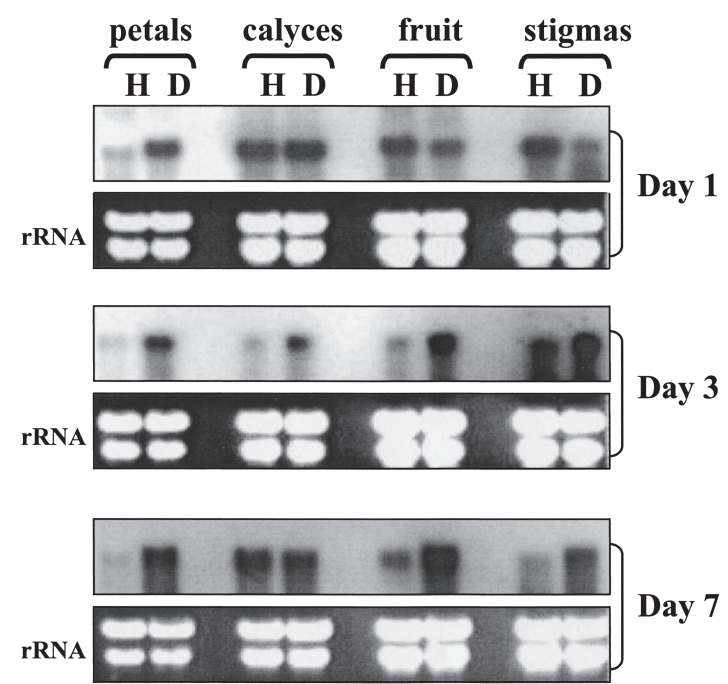

Fig. 3. Differential expression of ACC oxidase gene transcript in petals, calyces, small fruit, or stigmas of calamondin flowers. Total RNA was purified from different organs as indicated of the water control $(\mathrm{H})$ and the C. acutatuminfected (D) flowers 1,3, and $7 \mathrm{~d}$ postinoculation. Total RNA was denatured and separated in formaldehyde-containing gels, blotted to membranes, hybridized with a PCR-generated ACC oxidase gene probe (clone 64), and washed at high stringency. Gels were stained with ethidium bromide to ensure equal loading of the samples.

$5 \mathrm{~d}$ postinoculation. Furthermore, the genes encoding 12-oxophytodienoate reductase and ACC oxidase required for JA and ethylene biosynthesis, respectively, were also differentially expressed after $C$. acutatum infection. The results strongly indicated that infection of C. acutatum in the citrus flowers had directly or indirectly activated expression of genes associated with phytohormone biosynthesis or regulation. Further examination of gene expression revealed that the transcript of the gene encoding a putative ripening-related protein was not different between treatments, whereas the gene for senescence-induced nuclease was down-regulated after fungal infection (Fig. 1). Expression of the expansin, chitinase or endo-ß-1, 3-glucanase gene was slightly up-regulated. However, the transcript of the $\beta$-galactosidase gene decreased slightly in the affected calamondin flowers.

Similar patterns of differential gene expression in response to $C$ acutatum were also observed in 'Valencia' sweet orange flowers (Fig. 2). As in calamondin flowers, the gene transcripts of IAA glucose transferase, auxin-responsive GH3 protein, 12-oxophytodienoate

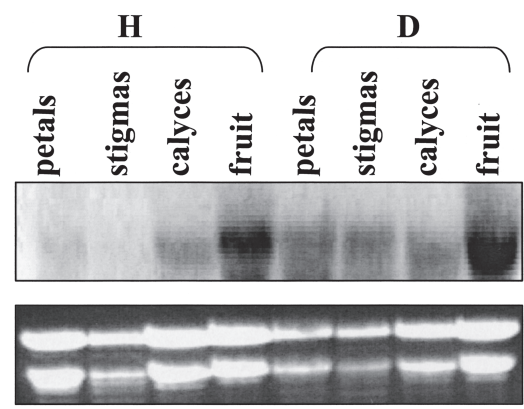

rRNA

Fig. 4. Spatial expression of 12-oxophytodienoate reductase gene transcript in petals calyces, small fruit, or stigmas of calamondin flowers. Total RNA was purified from different organs as indicated of the water control $(\mathrm{H})$ and the C. acutatum infected (D) flowers $7 \mathrm{~d}$ postinoculation. Total RNA was denatured and separated in a formaldehyde-containing gel, blotted to a membrane, and hybridized with PCR-generated 12-oxophytodienoate reductase gene probe (clone 159). Gel was stained with ethidium bromide to show loading of the samples. reductase, and ACC oxidase were also up-regulated, but the gene encoding IAA amino acid hydrase was slightly down-regulated in 'Valencia' sweet orange after infection. The results further confirmed the patterns of differential expression of those genes in response to C. acutatum. No differential expression was observed for the genes encoding the ripening-related protein and cell-wall modification enzymes (polygalacturonase, chitinase, endo- $\beta-1$, 3-glucanase) (Fig. 2). The gene encoding serine/threonine kinase was not differentially expressed in sweet orange.

Expression patterns of the ACC oxidase gene were further examined in various flower tissues and timing after $C$. acutatum infection. Northern-blot analysis revealed that the transcript of the ACC oxidase gene was barely detectable in the calamondin flower petals treated with water alone, but rapidly induced in the petals infected with $C$. acutatum $1 \mathrm{~d}$ postinoculation and continuously accumulated at a high level through $7 \mathrm{~d}$ (Fig. 3). Up-regulation of the ACC oxidase gene transcript was also observed in young fruit and stigmas at 3 and $7 \mathrm{~d}$ postinoculation, despite the apparent downregulation at day 1. No significant difference of the ACC oxidase gene transcript was observed in calyces 1 and $7 \mathrm{~d}$, whereas slight induction was detected in calyces $3 \mathrm{~d}$ postinoculation. Overall, the ACC oxidase gene transcript was accumulated to higher levels in the citrus flowers in response to C.acutatum colonization, implying that ethylene production is higher in infected flowers.

The gene encoding 12-oxophytodienoate reductase required for JA biosynthesis was also examined for its spatial expression in response to C. acutatum infection (Fig. 4). In control tissues, the gene transcript was highly expressed in young fruit, but barely detectable in petals, calyces, and stigmas $7 \mathrm{~d}$ postinoculation. Infection by $C$. acutatum apparently activated differential expression of the gene encoding12-oxophytodienoate reductase in petals, stigmas, and young fruit.

To further confirm the results of northern-blot analysis for the possible involvement of hormones in young fruit drop after $C$. acutatum infection, the concentrations of ethylene, IAA, and ABA were determined in calamondin flowers treated with water or $C$. acutatum (Table 2). After infection, ethylene and IAA increased significantly in citrus flowers. The ethylene concentration in infected flower tissues compared to the water controls increased by 3 -fold $5 \mathrm{~d}$ postinoculation. IAA accumulation in the infected petals was as much as 140 times that of the water control. ABA, however, showed no significant difference between two treatments.

\section{Discussion}

Postbloom fruit drop of citrus, caused by $C$. acutatum, results in severe drop of young fruit, formation of persistent calyces, and leaf distortion, suggesting hormones are involved in symptom development (Timmer and Brown, 2000). However, the nature of these hormones has never been investigated. In this study we investigated the differential expression patterns of genes that are

Table 2. Induction of plant hormones in calamondin flowers $5 \mathrm{~d}$ after $C$. acutatum infection. Ethylene was measured by gas chromatograph. IAA and ABA were purified, then further separated by HPLC, and quantified by ELISA using monoclonal antibodies. The data shown are the means of two different experiments with three replications for each treatment.

\begin{tabular}{lccc}
\hline Treatment & $\begin{array}{c}\text { Ethylene } \\
(\mathrm{nL} / \text { flower })\end{array}$ & $\begin{array}{c}\text { IAA } \\
\left(\mathrm{pmol} \cdot \mathrm{g}^{-1} \text { fresh } \mathrm{wt}\right)\end{array}$ & $\begin{array}{c}\text { ABA } \\
\left(\mathrm{pmol} \cdot \mathrm{g}^{-1} \text { fresh wt }\right)\end{array}$ \\
\hline Water & $5.7 \pm 0.7$ & $65.8 \pm 9.3$ & $56.0 \pm 5.0$ \\
C. acutatum & $18.2 \pm 2.8$ & $9526.4 \pm 102$ & $61.6 \pm 7.6$ \\
\hline
\end{tabular}


up-regulated in the mature citrus fruit during abscission (Burns, 2002) to evaluate if those genes are differentially regulated in the citrus flowers infected with $C$. acutatum. Analyses of gene expression profiles revealed that the genes encoding ethylene and JA biosyntheses, and IAA regulation were highly induced in both calamondin and 'Valencia' sweet orange challenged with the fungus $C$. acutatum. Analyses of the contents of ethylene and IAA also indicated that both hormones significantly accumulated in citrus flowers after $C$. acutatum infection. The data provide the first direct evidence to support the hypothesis for the involvement of hormones in citrus postbloom fruit drop caused by $C$. acutatum.

The plant hormone ethylene plays a pivotal role in regulation of many developmental and stress responses in plants (Abeles et al., 1992). The role of ethylene in fruit abscission has been well documented (Davenport and Manners, 1983; Goren, 1993; Miller et al., 1988; Nunez-Elisea and Davenport, 1986). In many plants, the primary regulation of ethylene biosynthesis by environmental and endogenous signals is through differential expression of ACC synthase and ACC oxidase genes (Bleecker and Kende, 2000; Bonghi et al., 2000). Colletotrichum acutatum causes drop of young fruit. Thus, after infection, higher transcript levels of the gene encoding ACC oxidase, a key enzyme for ethylene biosynthesis are detected. Induction of the ACC oxidase gene expression by $C$. acutatum infection could be detected as early as $1 \mathrm{~d}$ postinoculation and the transcript continued to accumulate for 7 $\mathrm{d}$. The highest induction was detected in petals where the fungus initiated infection, clearly indicating that elevation of the ACC oxidase gene transcript is correlated with pathogen colonization. Differential expression of ACC oxidase gene was also observed in young fruit, stigmas, and calyces. Analysis of ethylene concentration by gas chromatograph reveals a 3 -fold increase in the flowers infected with $C$. acutatum as compared to that of the water control, further confirming the expression pattern of ACC oxidase gene. The results also implicate ethylene involvement in citrus fruit drop caused by C. acutatum.

Formation of persistent calyces and leaf distortion with enlarged veins in $C$. acutatum-affected citrus may result from excessive amounts of IAA and/or other hormones. Gene expression profiles in this study support this. IAA glucose transferase is an enzyme responsible for a reversible reaction involved in the synthesis of 1-O-ß-indole-3-ylacetyl-glucose from uridine 5'-diphosphate-glucose (Szerszen et al., 1994). The gene encoding IAA glucose transferase was highly expressed, indicating a change in endogenous IAA occurs after $C$. acutatum infection. Since IAA glucose transferase has reversible activity (Szerszen et al., 1994), it can also release free IAA from conjugates. Based on various symptoms associated with PFD, higher amounts of IAA after C. acutatum infection would be expected. This hypothesis was further supported by the detection of higher expression levels of an auxin-responsive GH3-like gene that has been demonstrated to be activated by IAA in tobacco (Nicotiana tabacum) (Roux et al., 1998). Furthermore, the amount of IAA after fungal infection increased over 140 times, verifying the gene expression data. High levels of IAA may also result from de novo biosynthesis from the host plant and/or the fungal pathogen. Interestingly, $C$. acutatum isolates were found to produce high level of indole compounds in culture (Chung et al., unpublished data), implying that $C$. acutatum plays a substantial role in elevating IAA levels. In contrast to IAA glucose transferase, the IAA amino acid hydrolysis played a minor role in increasing IAA since its transcript remained constitutively expressed after $C$. acutatum infection.
JA and its methyl ester (methyl JA) have been demonstrated to be involved in various aspects of plant physiological functions including fruit ripening and pathogen resistance (Creelman and Mullet, 1995, 1997). Early studies showed that JA and its derivatives promoted senescence and acted as a growth regulator. The 12-oxophytodienoate reductase is one of the key enzymes involved in JA biosynthesis (Sanders et al., 2000). In this study, the gene encoding 12-oxophytodienoate reductase was only barely detectable in healthy citrus flowers, but highly inducible by $C$. acutatum infection in petals, stigmas and fruitlets. An increase in transcription of the 12-oxophytodienoate reductase gene suggests that $C$. acutatum may trigger higher production levels of JA. JA has been demonstrated to cause mature fruit abscission in citrus (Hartmond et al., 2000). As in the mature fruit, JA may also be involved in young fruit drop caused by $C$. acutatum. We did not measure the JA content, but a higher JA content likely occurred after fungal infection.

The role of ABA in fruit drop remains uncertain. However, a close relationship between ABA concentration and abscission of citrus fruit has been suggested (Talon et al., 1997). We measured the $\mathrm{ABA}$ content and found that $\mathrm{ABA}$ was not significantly changed in citrus flowers after fungal infection, suggesting that ABA may play little or no role in young fruit drop caused by C. acutatum.

Except for higher expression of gene transcripts for hormone regulation and biosynthesis, infection by $C$. acutatum also triggered differential expression of the gene encoding expansin in calamondin flowers. Expansins are a group of proteins involved in cell wall loosening and extension with a possible role in fruit ripening (Harrison et al., 2001; McQueen-Mason et al., 1992). Higher levels of the expansin gene transcripts in diseased flowers may imply that expansin activity is in part involved in young fruit drop. However, no differential expression of the expansin gene transcript was observed in sweet orange flowers. The level of expansin in abscission zones and its involvement in fruit drop requires further investigation. The chitinase and endo- $3-1,3$-glucanase genes, but not $\beta$-galactosidase gene, were up-regulated after $C$. acutatum infection in calamondin flowers. However, no differentiation of these genes was observed in sweet orange. Although no cultivar of citrus resistant to C. acutatum has been identified, differential expression of chitinase and endo- $\beta-1,3-$ glucanase genes in calamondin may indicate a defensive response to fungal invasion. Many chitinase genes are major pathogenesisrelated (PR) genes and have been demonstrated to be highly inducible by various biotic and abiotic stresses (Van Loon and Van Strien, 1999). A group of chitinase genes is also associated with fruit ripening in grape (Vitis vinifera L.) (Robinson et al., 1997). Other cell-wall degrading enzymes including glucanase, polygalacturonase, and cellulase have also been shown to be associated with fruit abscission in various plants (Bonghi et al., 2000). Although no differential gene expressions of endo- $\beta-1,3-$ glucanase, B-galactosidase, or polygalacturonase were detected in citrus after $C$. acutatum infection, their roles in PFD cannot be completely ruled out. The gene encoding senescence-related protein has been shown to be involved in leaf and stem senescence in Arabidopsis (Pérez-Amador et al., 2000), however, its expression was strongly inhibited in calamondin flowers after C. acutatum infection.

Many plant species, including citrus, set excess flowers and fruit, and undergo physiological drop of immature fruit to adjust fruit load. The mechanisms in which natural drop occurs during early fruit development are highly variable between species and have been investigated in some detail (Bangerth, 2000; Bonghi et 
al., 2000; Gómez-Cadenas et al., 2000). The processes of natural young fruit drop are complex and are apparently involved in degree of fertilization, disturbances in embryogenesis, adverse environmental conditions, nutrient competition, and hormone regulations (Bonghi et al., 2000). Among hormones, ethylene and auxin have been tightly linked to young fruit abscission, and may contribute to young fruit drop caused by $C$. acutatum. The higher levels of gene transcripts related to IAA regulation, JA and ethylene synthesis, and higher levels of IAA and ethylene contents were detected in affected flowers, further confirming their possible roles in young fruit drop.

Although higher transcription levels do not always reflect the levels of translation, identification of genes differentially expressed during $C$. acutatum infection provides a strong indication for the types of phytohormones that are likely involved in postbloom fruit drop. In this study, we have established a close correlation between gene expression and hormone accumulation using gene expression profiles and biochemical analyses. The results indicated that infection by C. acutatum triggered marked changes in IAA, ethylene, and JA, which may directly and indirectly attribute to the development of young fruit drop and other symptoms. Further investigations using inhibitors for IAA, ethylene, and/or JA biosynthesis will be necessary to elucidate the mechanisms by which the fungus causes fruit drop and other symptoms.

\section{Literature Cited}

Abeles F.B., P.W. Morgan, and M.E. Saltveit, Jr. 1992. Ethylene in Plant Biology. Academic Press, San Diego.

Bangerth, F. 2000. Abscission and thinning of young fruit and their regulation by plant hormones and bioregulators. Plant Growth Reg. 31:43-59.

Bleecker, A.B. and H. Kende. 2000. Ethylene: A gaseous signal molecule in plants. Annu. Rev. Cell Dev. Biol. 16:1-18.

Bonghi, C., P. Tonutti, and A. Ramina. 2000. Biochemical and molecular aspects of fruitlet abscission. Plant Growth Reg. 31:35-42.

Burns, J.K. 2002. Using molecular biology tools to identify abscission materials for citrus. HortScience 37:459-464.

Chung, K.-R., A. Leuchtmann, and C.L. Schardl. 1996. Inheritance of mitochondrial DNA and plasmids in the ascomycetous fungus, Epichloe typhina. Genetics 142:259-265.

Chung, K.-R., T. Shilts, W. Li, and L.W. Timmer. 2002. Engineering a genetic transformation system for Colletotrichum acutatum, the causal fungus of lime anthracnose and postbloom fruit drop of citrus. FEMS Microbiol. Lett. 213:33-39.

Creelman, R.A. and J.E. Mullet. 1995. Jasmonic acid distribution and action in plants: Regulation during development and response to biotic and abiotic stress. Proc. Natl. Acad. Sci. USA 92:4114-4119.

Creelman, R.A. and J.E. Mullet. 1997. Biosynthesis and action of jasmonates in plants. Annu. Rev. Plant Physiol. Plant Mol. Biol. 48: $355-381$.

Davenport, T.L. and M. Manners. 1983. Nucellar senescence and ethylene production as they relate to avocado fruitlet abscission. J. Exp. Bot. 33:815-825.

Fagan, H.J. 1979. Postbloom fruit drop, a new disease of citrus associated with a form of Colletotrichum gloeosporioides. Ann. Appl. Biol.
91:13-20.

Gómez-Cadenas, A., J. Mehouachi, F.R. Tadeo, E. Primo-Millo, and M. Talon. 2000. Hormonal regulation of fruitlet abscission induced by carbohydrate shortage in citrus. Planta 210:636-643.

Goren, G. 1993. Anatomical, physiological, and hormonal aspects of abscission in citrus. Hort. Rev. 15:33-46.

Harrison, E.P., S.J. McQueen-Mason, and K. Manning. 2001. Expression of six expansin genes in relation to extension activity in developing strawberry fruit. J. Exp. Bot. 52:1437-1446.

Hartmond, U., R. Yuan, J.K. Burns, A. Grant, and W.J. Kender. 2000 Citrus fruit abscission induced by methyl-jasmonate. J. Amer. Soc. Hort. Sci. 125:547-552.

McQueen-Mason, S., S.J. Durachko, and D.J. Cosgrove. 1992. Two endogenous proteins that induce cell wall extension in plants. Plant Cell 4:1425-1433.

Miller, A.N., C.S. Walsh, and J.D. Cohen. 1987. Measurement of indole3 -acetic acid in peach fruits (Prunus persica $\mathrm{L}$. Batsch cv Redhaven) during development. Plant Physiol. 84:491-494.

Miller, AN., B.A. Krizek, and C.S. Walsh. 1988. Whole fruit ethylene evolution and ACC content. J. Amer. Soc. Hort. Sci. 113:119-124.

Nunez-Elisea, R. and T.L. Davenport. 1986. Abscission of mango fruitlets as influenced by enhanced ethylene biosynthesis. Plant Physiol. 82:991-994.

Pérez-Amador, M.A., M.L. Abler, E.J. De Rocher, D.M. Thompson, A. van Hoof, N.D. LeBrasseur, A. Lers, and P.J. Green. 2000. Identification of BFN1, a bifunctional nuclease induced during leaf and stem senescence in Arabidopsis. Plant Physiol. 122:169-180.

Robinson, S.P., A.K. Jacobs, and I.B. Dry. 1997. A class IV chitinase is highly expressed in grape berries during ripening. Plant Physiol. 114:771-778.

Roux, C., J. Bilang, B.H. Theunissen, and C. Perrot-Rechenmann. 1998 Identification of new early auxin markers in tobacco by mRNA differential display. Plant Mol. Biol. 37:385-389.

Sanders, P.M., P.Y. Lee, C. Biesgen, J.D. Boone, T.P. Beals, E.W. Weiler, and R.B. Goldberg. 2000. The Arabidopsis DELAYED DEHISCENCE1 gene encodes an enzyme in the jasmonic acid synthesis pathway. Plant Cell 12:1041-1061.

Szerszen, J.B., K. Szczyglowski, and R.S. Bandurski. 1994. iaglu, a gene from Zea mays involved in conjugation of growth hormone indole-3acetic acid. Science 265:1699-1701.

Talon, M.,F.R. Tadeo, W. Ben-Cheikl, A. Gomez-Cadenas, J. Mehouachi, J. Perez-Botella, and E. Primo-Millo. 1997. Hormonal regulation of fruit set and abscission in Citrus: Classical concepts and new evidence. Acta Hort. 463:209-217.

Timmer, L.W. and G.E. Brown. 2000. Biology and control of anthracnose diseases of citrus, p. 300-316. In: D. Prusky, S. Freeman, and M.B. Dickman (eds.). Colletotrichum: Host specificity, pathology, and host-pathogen interaction, APS Press, St Paul, Minn.

Timmer, L.W., J.P.Agostini, S.E. Zitko, and M.Zulfiqar. 1994. Postbloom fruit drop, an increasingly prevalent disease of citrus in the America's. Plant Dis. 78:329-334.

Van Loon, L.C. and E.A. Van Strien. 1999. The families of pathogenesisrelated proteins, their activities, and comparative analysis of PR-1 type proteins. Physiol. Mol. Plant Pathol. 55:85-97.

Yuan, R., U. Hartmond, and J.W. Kender. 2001. Physiological factors affecting response of mature 'Valencia' orange fruit to CMN-pyrazole. II. Endogenous concentrations of indole-3-acetic acid, abscisic acid, and ethylene. J. Amer. Soc. Hort. Sci. 126:420-426. 